短 報

\section{クレン運転工の訓練時技能と 奥行感営について}

Relation between Skill and Stereognosis of Crayne Operators in their Probationary Period

クレンの運転作業には，立体視あるいは物体の奥行を 知覚する能力が必須とされている. しかし, 従来からク レンマンとして配置するさい，これらのチェックがなさ れていないため，われわれはその機能不良により，接触 などの事故災害を頻発したと思われる事例を二, 三経験 している.これら事故災害者は心理適性検査において異 常がなく, 眼科専門医による精密検診の結果, 立体視不 良を確認されたものである，以上から，運転技能が立体 視あるいは奥行感覚によって, どのように影響されるか を実証的に検討し，あわせて適性基準を見いだすことを 目的とした.

\section{方 法}

1. 対象者：某製鉄所において，昭和41年から同44年 までの期間に，クレンマンを養成するための特別教育計 画に基づき，各職場から選ばれた従業員 250 名を対象と した. すなわち， 1 回に約 50 名ずつを養成し， 5 回にわ たり教育センターに打いて訓練した．その年跉は22 45 歳で平均年齢は27歳（標準偏差 5 ）であった.

2. 技能の評価：クレンマンとしての基礎訓練は学科 11日間, 実習13日間である。それらの完了時に, 実際の クレンを用いて実技のテストを行ない，その得点をもっ て技能の基準とした．実技テストは幅，高さの障害やU ターンを含むるので, 速さと正確さを総合評定してい る. 技能点の上位 $20 \%$ と下位 $20 \%$ をめやすとして，技 能上位群, 下位群とし, 残りを中位群とした.

3. 視力湘定 : 250 名の5ち, 前半の 119 名について は, 従来から用いられている二柱法1)による奥行感覚を 測定した。これは $5 \mathrm{~m}$ の距離から 2 回実施して平均值を とっている. また後半の 131 名については, スクリノス コープ2）（視機能検查器, 遠距離は $6 \mathrm{~m}$ および近距離は $30 \mathrm{~cm}$ に打ける両眼, 左右の視力, 立体視, 斜位, 乱視 などを回転ノブをまわすことにより，迅速に連続測定す る）を入手したのでここを用いて $6 \mathrm{~m}$ における視力 と，立体視を測定した. スクリノスコープによる視力は No. 1 (視力 0.1) から No. 12（視力 1.5）まで, 立体 視はNo. 0 から No. 6 までが測定可能な範囲であり，
いずれも No. が大なるほど機能は良好である. メガネ 使用者はすべて矯正時の視力を測った。

\section{結果と考寮}

1. 二柱法による奥行感覚と技能：技能上位群と下位 群の奥行感覚間には有意な差がない(図 1). しかし、下 位群のほうに二柱間の距離の大きな機能不良者が存在す る. 従来, 二柱法に用いられている基準の $3.6 \mathrm{~cm}$ 以上 不適といら線で切ると, 不適圈内に技能上位者が 1 名

（4\%）であるのに対し，技能下位者 3 名 (10\%) が含 まれる。

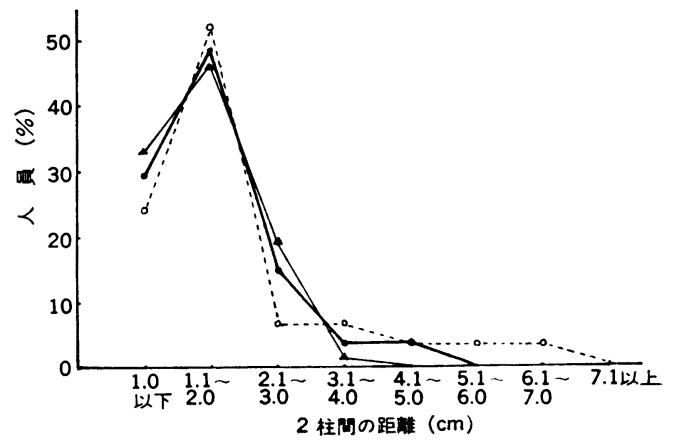

因1. 奥行感覚とクレン運転技能（2 柱検査法によ る. 距離 $5 \mathrm{~m}$ )

-上位群 $N=27, \Delta$ 中位群 $N=63$, ○下位群 $N=$ 29

2. スクリノスコープによる視力と技能: 技能上位群 と下位群の両眼視力間には有意な差がない(図2). 今回 の対象者の視力分布はスクリノスコープの No. 6 (視力 0.6) 以上であるが，この範囲内では視力と技能との間 に関連がないようである.スクリノスコープの手引きに よると, 運転作業の基準は No. 7 8 を要注意, No. 9 以上を適としている.

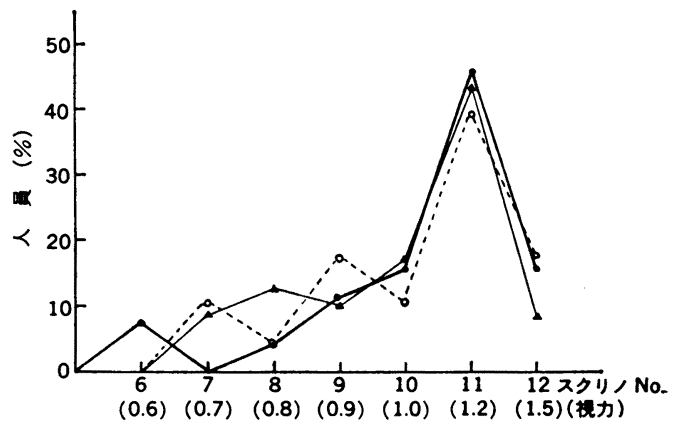

四2. 両眼視力とクレン運転技能（スクリノスコー プによる. 距離 $6 \mathrm{~m}$ )

-上位群 $N=26, \triangle$ 中位群 $N=77$, ○下位群 $N=$ 28 
3. スクリノスコープによる立体視と技能 : 技能上位 群は, 立体視 No. 5 と No. 6 に集中しているのに対 し，下位群はそれ以下にも分布しており，No. 1 あるい はNo. 0 など立体視の極端に劣る者が存在する(図 3). したがって, No. 5 (立体視角度 $27^{\prime \prime}$ ) 以上を適とすれ ば，両群の分離はかなり良好である（技能上位群は立体 視 No. 5 以上 26 名, No. 4 以下 0 名, 技能下位群は立 体視 No. 5 以上20名, No. 4 以下 8 名であり, Fisher の直接確率検定 $\mathrm{P}<0.01)$. スクリノスコープの手引き による運転作業基準もこれと同じである.

スクリノスコープ群と二柱法群とは対象者を異にする ので, 厳密に両測定法を比較することはできないが，今 回の結果からみると, 前者の立体視による弁別がすぐれ ている.これはスクリノスコープの測定精度が高いこと や, 当装置による立体視がたんなる奥行感覚よりも実際 の運転作業と関連が深いためと考えられる.

\section{むすび}

クレンの運転技能が研修完了時に劣っていたものには 立体視不良者が有意に多く含まれていた。したがって， これを配置前に検查するのが望ましいと考穴られる。な お，今回は訓練時の技能を基準としたので，これが実務 時の技能とどの程度一致するかが問題であるが, それは 今後の追跡調査の結果をまたねばならない。

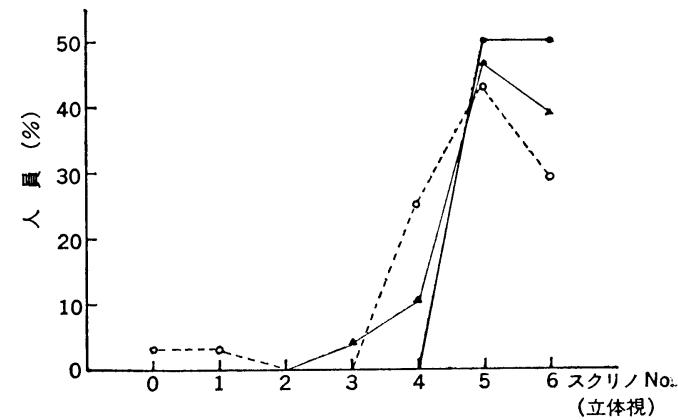

四3. 立体視とクレン運転技能（スクリノスコープ による. 距離 $6 \mathrm{~m}$ )

-上位群 $N=26, \Delta$ 中位群 $N=77$, ○下位群 $N=$ 28

この報告は昭和48年度日本産業衛生学会九州地方会において 発表した.

\section{文 献}

1）労働科学研究所編：適性検査マニアル（産業用），109， 労働科学研究所出版部, 東京, 1969 .

2) 東京光学機械編: SCREENOSCOPE 使用手引, 東京 光学機械 K.K.

\section{境 知厚}

\section{新日本製鉄(株) 八橎製鉄所衛生課}

Tomoatsu SAKAI

Yawata Works, Nippon Steel Corporation 昭和48年 6 月 12 日受付 